\title{
AKTIVITAS EKSTRAK ETANOL BERAS KETAN HITAM (ORYZA SATIVA L. VAR GLUTINOSA) TERHADAP PENURUNAN KADAR GLUKOSA DARAH MENCIT (MUS MUSCULUS)
}

\author{
Dian Suasana*, Welinda Dyah Ayu, Arsyik Ibrahim \\ Laboratorium Penelitian dan Pengembangan FARMAKA TROPIS \\ Fakultas Farmasi Universitas Mulawarman, Samarinda, Kalimantan Timur \\ *Email: dianrahimin@gmail.com
}

\begin{abstract}
ABSTRAK
Diabetes melitus memiliki prevalensi yang cenderung meningkat dari tahun ke tahun sehingga dibutuhkan obat yang efektif dengan efek samping minimal untuk menanggulangi sindroma metabolik ini. Salah satu tanaman yang secara empiris banyak digunakan masyarakat untuk pengobatan diabetes adalah beras ketan hitam (Oryza sativa L. var glutinosa). Penelitian ini bertujuan mengetahui rendemen, metabolit sekunder, aktivitas, dan dosis efektif dari ekstrak beras ketan hitam dalam menurunkan kadar glukosa darah mencit (Mus musculus) diabetik. Untuk meningkatkan kadar glukosa darah digunakan aloksan. Selanjutnya dilakukan pemberian ekstrak beras ketan hitam dengan variasi dosis $195 \mathrm{mg} / \mathrm{kg} \mathrm{BB} ; 390 \mathrm{mg} / \mathrm{kg} \mathrm{BB} ; 780 \mathrm{mg} / \mathrm{kg} \mathrm{BB}$, kontrol negatif, kontrol normal, dan Glibenklamid sebagai kontrol positif. Pengukuran kadar glukosa darah dilakukan pada hari ke- 0, 2, 4, 6, 8, dan 10 menggunakan glukometer. Hasil perhitungan rendemen ekstrak etanol beras ketan hitam diperoleh sebesar $1,44 \%$ dan terdeteksi metabolit sekunder berupa senyawa golongan fenol, saponin, flavonoid, alkaloid, dan tanin. Hasil analisis data kadar glukosa darah menunjukkan ekstrak etanol beras ketan hitam memiliki aktivitas dalam penurunan kadar glukosa darah $(\rho<0.01)$ dengan dosis paling efektif $195 \mathrm{mg} / \mathrm{kg} \mathrm{BB}$ yang bila dibandingkan dengan Glibenklamid diperoleh nilai $\rho>0.05$ dalam menurunkan kadar glukosa darah sehingga dapat disimpulkan ekstrak etanol beras ketan hitam memiliki aktivitas dalam menurunkan kadar glukosa darah.
\end{abstract}

Kata Kunci : beras ketan hitam, aloksan, penurunan glukosa darah

\begin{abstract}
Diabetes mellitus prevalence has increased from year to year so it required effective drugs with minimal side effects to overcome this metabolic syndrome. One of the plants that are empirically many people use for treatment of diabetes mellitus is black glutinous rice (Oryza sativa L. var glutinosa). The study aims to determine the yield, secondary metabolites, activity, and an effective dose of black glutinous rice extract in lowering blood glucose levels in diabetic mice (Mus musculus). To increase blood glucose levels are used alloxan. The research doing by given the extract of black glutinous rice with a variety doses $195 \mathrm{mg} / \mathrm{kg} \mathrm{BW} ; 390 \mathrm{mg} / \mathrm{kg} \mathrm{BW} ; 780 \mathrm{mg} / \mathrm{kg} \mathrm{BW}$, negative control, normal control, and Glibenclamide as a positive control. The blood glucose measured by Glucometer on days $0,2,4,6,8$, and 10 . The result of the calculation yield of black glutinous rice ethanol extract gained for $1,44 \%$ and secondary metabolites detected is compounds of phenols, saponins, flavonoids, alkaloids, and tannins. The results of the data analysis of blood
\end{abstract}


glucose levels showed the ethanol extract of black glutinous rice have activity in lowering blood glucose levels $(\rho<0.01)$ with the most effective dose $195 \mathrm{mg} / \mathrm{kg}$ BW when compared with glibenclamide obtained value $\rho>0.05$ in lowering blood glucose levels. In conclusion, the ethanol extract of black glutinous rice have activity lowering in blood glucose levels.

Keywords: black glutinous rice, alloxan, blood glucose lowered

\section{PENDAHULUAN}

Diabetes melitus (DM) merupakan suatu kelompok penyakit metabolik yang ditandai dengan terjadinya hiperglikemia karena kelainan sekresi insulin atau gangguan pada reseptor insulin (Gustaviani, 2006). Diabetes melitus berhubungan dengan metabolisme karbohidrat, protein, dan lemak. Ada dua tipe utama diabetes melitus, yaitu insulindependent diabetes mellitus (tipe 1) dan non-insulin-dependent diabetes mellitus (tipe 2) (Burtis dkk., 1988). Badan kesehatan dunia, World Health Organization (WHO) (2012) melaporkan sebanyak 2,8 juta orang meninggal setiap tahun akibat penyakit obesitas dan diabetes. Diperkirakan prevalensi diabetes meningkat dari 6,4\% (285 jiwa) pada tahun 2010 menjadi 7,7\% (439 juta jiwa) pada tahun 2030 (Shaw, dkk., 2010).

Diabetes melitus merupakan penyakit kronis yang dapat menyebabkan komplikasi seperti penyakit kardiovaskuler, kegagalan ginjal kronis, kerusakan retina yang dapat menyebabkan kebutaan, kerusakan syaraf, impotensi dan gangren dengan risiko amputasi sehingga penderita DM harus memakai obat secara rutin dengan biaya mahal. Disamping itu, pemakaian obat terus menerus dalam waktu cukup lama bahkan seumur hidup akan menimbulkan efek samping yang membahayakan bahkan dapat menyebabkan kematian. WHO merekomendasikan penggunaan obat tradisional termasuk obat herbal dalam pemeliharaan kesehatan masyarakat, pencegahan dan pengobatan penyakit, terutama untuk penyakit kronis, degeneratif dan kanker. Penyelidikan secara ekstensif terhadap tumbuhan berkhasiat obat terus dilakukan guna penemuan obat baru (Daud, 2013).

Tanaman obat banyak digunakan masyarakat menengah ke bawah terutama dalam upaya preventif, promotif, dan rehabilitas. Sementara itu banyak orang beranggapan bahwa penggunaan tanaman obat relatif lebih aman dibandingkan obat sintesis. Walaupun demikian bukan berarti tanaman obat tidak memiliki efek samping yang merugikan, bila cara penggunaan dan takarannya kurang tepat. Agar penggunaannya optimal, perlu diketahui informasi yang memadai tentang kebenaran, keamanan, dan khasiat tanaman obat tersebut (Katno dan Pramono, 2003).

Beras ketan hitam merupakan salah satu tanaman yang potensial sebagai sumber energi, antioksidan, senyawa bioaktif, dan serat yang penting bagi kesehatan. Warna hitam kemerahan beras ketan hitam disebabkan oleh sel-sel pada kulit ari yang mengandung antosianin. Beberapa fungsi antosianin adalah sebagai antioksidan dalam tubuh, sebagai senyawa antiinflamasi, menghambat sel tumor, serta mampu mencegah obesitas dan diabetes (Nailufar dkk., 2012).

Menurut Herbarium Medanense (2011) dalam sistematika tumbuhan, ketan hitam diklasifikasikan sebagai berikut:

$\begin{array}{ll}\text { Kingdom } & \text { : Plantae } \\ \text { Divisi } & \text { : Spermatophyta } \\ \text { Kelas } & \text { : Monocotyledoneae } \\ \text { Ordo } & \text { : Poales } \\ \text { Famili } & \text { : Poaceae } \\ \text { Genus } & \text { : Oryza }\end{array}$


Spesis

: Oryza sativa L. var

glutinosa

Tanaman beras ketan hitam (Oryza sativa L. var glutinosa) secara empiris sering digunakan pada masyarakat untuk mengobati diabetes melitus. Seperti yang dilakukan masyarakat Kecamatan Samboja Provinsi Kalimantan Timur, pengobatan diabetes melitus dengan beras ketan hitam dilakukan dengan menyeduh beras ketan hitam dengan air panas hingga diperoleh air seduhan berwarna merah kehitaman. Air seduhan didinginkan, kemudian diminum sebanyak 1-3 kali sehari.

Penelitian ini bertujuan untuk mengetahui rendemen, golongan metabolit sekunder dan aktivitas beserta dosis efektif ekstrak etanol beras ketan hitam (Oryza sativa var glutinosa) dalam menurunkan kadar glukosa darah mencit (Mus musculus) diabetik.

\section{METODE PENELITIAN}

\section{Bahan}

Bahan yang digunakan dalam penelitian yaitu beras ketan hitam, etanol $80 \%$, aloksan monohidrat, alkohol, aquades, Na-CMC, Glibenklamid, strip glukosa, pereaksi Meyer, pereaksi Dragendorf, asam klorida, larutan besi klorida (III), pita Mg, asam asetat anhidrat, kloroform, asam sulfat pekat, dan gelatin.

\section{Peralatan}

Peralatan yang digunakan dalam penelitian yaitu glukometer $\mathrm{NESCO}^{\circledR}$, gunting bedah, holder mencit, jarum suntik, lap kasar, gelas kimia, labu ukur, mortir dan stamper, pipet tetes, pipet ukur, rotary evaporator, sendok tanduk, spatel, batang pengaduk, spidol, spuit $1 \mathrm{~mL}$ dan $5 \mathrm{~mL}$, timbangan analitik, tabung reaksi, timbangan hewan uji, kandang hewan uji, dan toples kaca.

\section{Penyiapan Sampel}

Sampel yang digunakan dalam penelitian ini adalah biji padi beras ketan hitam yang terlebih dahulu dikeringkan kemudian dihilangkan gabahnya. Beras ketan hitam yang telah kering dan dihilangkan gabahnya diambil sebanyak $3 \mathrm{~kg}$ dan siap untuk diekstraksi.

\section{Pembuatan Ekstrak Etanol Beras Ketan Hitam}

Pembuatan ekstrak dilakukan dengan mengekstraksi sampel secara maserasi menggunakan pelarut etanol $80 \%$. Sampel beras ketan hitam sebanyak $3 \mathrm{~kg}$ dimasukkan ke dalam wadah toples kaca, lalu ditambahkan pelarut etanol $80 \%$ hingga sampel terendam seluruhnya dan diaduk. Wadah kemudian ditutup dan dibiarkan selama 3 hari sambil sesekali diaduk setiap 24 jam. Hasil ekstraksi kemudian disaring menggunakan kertas saring sehingga diperoleh filtrat dan residunya. Residu penyaringan dimaserasi kembali (remaserasi) hingga filtrat menjadi bening. Filtrat diuapkan menggunakan rotary evaporator pada suhu $55^{\circ} \mathrm{C}$ hingga diperoleh ekstrak kental. Ekstrak kental kemudian diuapkan pada suhu kamar hingga seluruh sisa pelarut menguap dan diperoleh ekstrak kering beras ketan hitam.

\section{Identifikasi Metabolit Sekunder}

Identifikasi metabolit sekunder dilakukan secara kualitatif yakni mengamati perubahan warna, endapan, atau buih setelah penambahan reagen kimia tertentu. Golongan metabolit sekunder yang diidentifikasi adalah alkaloid, fenol, flavonoid, saponin, steroid, dan tanin. 
Identifikasi alkaloid dilakukan dengan penambahan $\mathrm{HCl} 2 \%$ kemudian dibagi dalam 2 tabung. Tabung 1 ditambahkan pereaksi Dragendorf dan tabung 2 ditambahkan pereaksi Meyer. Positif terkandung alkaloid jika terbentuk endapan merah bata (tabung 1) dan terbentuk endapan putih (tabung 2) maka positif mengandung alkaloid. Identifikasi senyawa fenol dilakukan dengan penambahan $\mathrm{FeCl}^{3}$ dengan hasil positif adanya perubahan warna menjadi hijau atau biru kehitaman. Identifikasi flavonoid menggunakan etanol, $\mathrm{HCl}$ pekat, dan pita Mg. Positif mengandung flavonoid jika terbentuk warna jingga. Identifikasi saponin dilakukan dengan penambahan aquades lalu dikocok kuat dan ditambahkan $\mathrm{HCl}$ $2 \%$. Jika buih stabil maka positif mengandung saponin. Identifikasi steroid dilakukan dengan penambahan asam asetat anhidrat, kloroform, dan asam sulfat pekat. Hasil positif dengan adanya cincin merah kecoklatan atau ungu dibatas kedua larutan. Identifikasi tanin dengan penambahan gelatin dan $\mathrm{FeCl}^{3}$. Hasil positif jika terbentuk endapan putih setelah penambahan gelatin dan hijau atau biru kehitaman setelah penambahan $\mathrm{FeCl}^{3}$ (Depkes RI., 1996).

\section{Penyiapan Hewan Uji}

Hewan uji yang digunakan dalam penelitian ini adalah mencit jantan sebanyak 24 ekor dengan berat badan 24-38 gram dan dibagi dalam 6 kelompok uji yaitu 3 kelompok uji ekstrak; kontrol normal; kontrol negatif; dan kontrol positif masing-masing terdiri dari 4 ekor mencit. Mencit terlebih dahulu diaklimatisasi selama seminggu di kandang hewan Fakultas Farmasi Universitas Mulawarman dengan tujuan agar mencit beradaptasi dengan lingkungan baru dan meminimalisasi efek stress.

\section{Pengujian Aktivitas Penurunan Kadar Glukosa Darah}

Pengujian aktivitas ekstrak beras ketan hitam terhadap penurunan kadar glukosa darah mencit dilakukan dengan terlebih dahulu mengkondisikan hewan uji dalam keadaan hiperglikemia menggunakan aloksan. Seluruh kelompok hewan uji kecuali kelompok kontrol normal diinduksi menggunakan aloksan dengan dosis $150 \mathrm{mg} / \mathrm{kg}$ BB secara intraperitoneal. Sebelum induksi kadar glukosa darah awal terlebih dahulu diukur. Kadar glukosa darah kembali diukur 2 hari setelah penginduksian untuk mengetahui perkembangan hiperglikemia sampai kadar glukosa darahnya lebih dari $200 \mathrm{mg} / \mathrm{dL}$. Pengujian dilakukan sejak mencit dinyatakan diabetes. Kelompok 1 sebagai kontrol normal dan merupakan hewan uji non diabetik diberi perlakuan hanya dengan diet standar (pakan dan minum). Kelompok 2 sebagai kontrol negatif dengan perlakuan diberi diet standar dan $\mathrm{Na}-\mathrm{CMC} 0,5 \%$. Kelompok 3 sebagai kontrol positif dengan perlakuan diberi diet standar dan Glibenklamid 0,026 mg/20g BB. Kelompok 4, 5, dan 6 sebagai kelompok pengujian ekstrak dengan perlakuan diberi diet standar dan ekstrak etanol beras ketan hitam dengan variasi dosis $195 \mathrm{mg} / \mathrm{kg}$ bb; $380 \mathrm{mg} / \mathrm{kg} \mathrm{BB}$; dan $780 \mathrm{mg} / \mathrm{kg} \mathrm{BB}$. Pemberian dilakukan setiap hari selama 10 hari. Pengukuran kadar glukosa darah dilakukan pada hari ke- 0, 2, 4, 6, 8, dan 10 dengan mengambil darah melalui vena lateralis ekor mencit yang sebelumnya disterilkan dengan alkohol $70 \%$. Pengambilan dilakukan dengan menggunting ujung ekor mencit menggunakan gunting bedah. Kemudian dilakukan pemijatan perlahan terhadap ekor agar darah keluar. Darah lalu diteteskan pada strip glukosa dan glukometer akan menunjukkan kadar glukosa darah mencit yang terukur. Ujung ekor mencit yang telah dilukai kemudian diberi alkohol $70 \%$ untuk mencegah infeksi. Selanjutnya dilakukan observasi kadar glukosa darah sewaktu pada tiap kelompok dan analisis data.

\section{Analisis Data}

Analisis data pada data rendemen menggunakan persentase rendemen ekstrak terhadap simplisia awal. Analisis metabolit sekunder dilakukan secara tabulasi dimana jika 
terdapat reaksi adanya metabolit sekunder setelah pemberian reagen kimia diberi tanda positif (+) dan jika tidak terdapat metabolit sekunder diberi tanda negatif (-). Data aktivitas penurunan kadar glukosa dianalisis mengunakan ANAVA dua arah. Bila hasilnya signifikan maka dapat dilakukan uji lanjutan yang sesuai.

\section{HASIL DAN PEMBAHASAN}

\section{Rendemen Ekstrak Etanol Beras Ketan Hitam}

Ekstrak adalah sediaan kering, kental, atau cair dibuat dari simplisia nabati atau simplisia hewani yang diolah dengan cara yang tepat diluar pengaruh cahaya matahari langsung (Depkes RI., 1979). Sedangkan rendemen adalah perbandingan antara ekstrak yang diperoleh dengan simplisia awal (Depkes, 2000). Ekstrak beras ketan hitam diperoleh dengan ekstraksi secara maserasi menggunakan pelarut etanol $80 \%$. Campuran pelarut etanol-air dengan persentase $80 \%$ sebagai pelarut diketahui lebih baik dalam menarik senyawa-senyawa seperti flavonoid, alkaloid, tanin, dan minyak atsiri dibanding dengan etanol 95\%. Hal ini dikarenakan campuran etanol-air mengakibatkan perubahan polaritas dari pelarut sehingga akan mempengaruhi jumlah dan jenis senyawa kimia yang tersari (Lestari dan Yohanes, 2014). Menurut Sihombing, dkk. (2008) maserasi merupakan metode ekstraksi cara dingin sehingga zat-zat yang terkandung di dalam simplisia relatif lebih aman jika dibandingkan dengan penggunaan ekstraksi cara panas. Data persentase rendemen ekstrak beras ketan hitam dapat dilihat pada tabel 1 berikut:

Tabel 1. Rendemen Ekstrak Etanol Beras Ketan Hitam

\begin{tabular}{cc}
\hline Sampel & Jumlah (gram atau \%) \\
\hline Simplisia kering & 3000 gram \\
Ekstrak & 43,1 gram \\
\hline Persentase rendemen & $1,44 \%$ \\
\hline
\end{tabular}

\section{Metabolit Sekunder Ekstrak Etanol Beras Ketan Hitam}

Metabolit sekunder merupakan senyawa yang disintesis oleh suatu makhluk hidup bukan untuk memenuhi kebutuhan dasarnya, tetapi untuk mempertahankan eksistensinya dalam berinteraksi dengan lingkungan hidup seperti mempertahankan diri dari hama penyakit atau untuk berkompetisi dengan makhluk hidup lain di sekitarnya. Hasil identifikasi metabolit sekunder ekstrak etanol beras ketan hitam dapat dilihat pada tabel 2.

Tabel 2. Metabolit Sekunder Ekstrak Etanol Beras Ketan Hitam

\begin{tabular}{ccc}
\hline Metabolit Sekunder & Hasil $(+/-)$ & Keterangan \\
\hline Alkaloid & + & Endapan merah bata \\
\hline Fenol & + & Larutan kehitaman \\
\hline Flavonoid & + & Larutan jingga \\
\hline Saponin & + & Buih stabil \\
\hline Steroid & - & $\begin{array}{c}\text { Tidak terbentuk cincin } \\
\text { merah kecoklatan }\end{array}$ \\
\hline Tanin & + & Larutan kehitaman \\
\hline
\end{tabular}

Keterangan:

(-) : : tidak teridentifikasi metabolit sekunder

(+) : teridentifikasi metabolit sekunder 
Berdasarkan tabel 2 diketahui ekstrak etanol beras ketan hitam terdeteksi senyawa metabolit sekunder golongan alkaloid, fenol, flavonoid, saponin, dan tanin.

\section{Aktivitas Penurunan Kadar Glukosa Darah Ekstrak Beras Ketan Hitam}

Pengujian aktivitas penurunan kadar glukosa darah dari ekstrak etanol beras ketan hitam dilakukan dengan terlebih dahulu mengkondisikan hewan uji dalam keadaan diabetes menggunakan aloksan. Aloksan diinduksikan pada mencit pada bagian intraperitoneal dengan dosis $150 \mathrm{mg} / \mathrm{kg} \mathrm{BB}$. Aloksan merupakan suatu substrat yang secara struktural adalah derivat pirimidin sederhana. Aloksan mempunyai kemampuan untuk merusak sel beta pankreas dan menghasilkan kondisi diabetik eksperimental (hiperglikemia) pada hewan uji. Aloksan dalam darah berikatan dengan GLUT-2 yang memfasilitasi aloksan masuk ke dalam sel beta pankreas. Di dalam sel beta pankreas, aloksan menginduksi pengeluaran ion kalsium dari mitokondria yang mengakibatkan proses oksidasi sel terganggu. Keluarnya ion kalsium dari mitokondria ini mengakibatkan gangguan homeostasis yang merupakan awal dari matinya sel (Suharmiati, 2003). Teori lain menerangkan aloksan mengakibatkan terjadinya pembentukan reactive oxygen species (ROS) menghasilkan dialuric acid. Dialuric acid ini mengalami siklus redoks dan membentuk radikal superoksida. Radikal ini akan mengalami dismutasi menjadi hidrogen peroksida dan pada tahap akhir mengalami reaksi dengan katalis besi membentuk radikal hidroksil. Radikal hidroksil inilah yang menyebabkan kerusakan pada sel beta pankreas. Kondisi hiperglikemia akibat aloksan dapat terjadi 24 - 48 jam setelah induksi (Rohilla dan Ali, 2012). Mencit dengan kadar glukosa darah sewaktu lebih dari $200 \mathrm{mg} / \mathrm{dL}$ dinyatakan diabetes dan dapat diberi perlakuan (pemberian ekstrak etanol beras ketan hitam dosis 195 $\mathrm{mg} / \mathrm{kg} \mathrm{BB} ; 390 \mathrm{mg} / \mathrm{kg} \mathrm{BB} ; 780 \mathrm{mg} / \mathrm{kg} \mathrm{BB}, \mathrm{Na}-\mathrm{CMC}$, atau Glibenklamid). Kadar glukosa darah kemudian diukur pada hari ke-0, 2, 4, 6, dan 10 untuk mengetahui aktivitas penurunan kadar glukosa darah dari tiap kelompok uji.

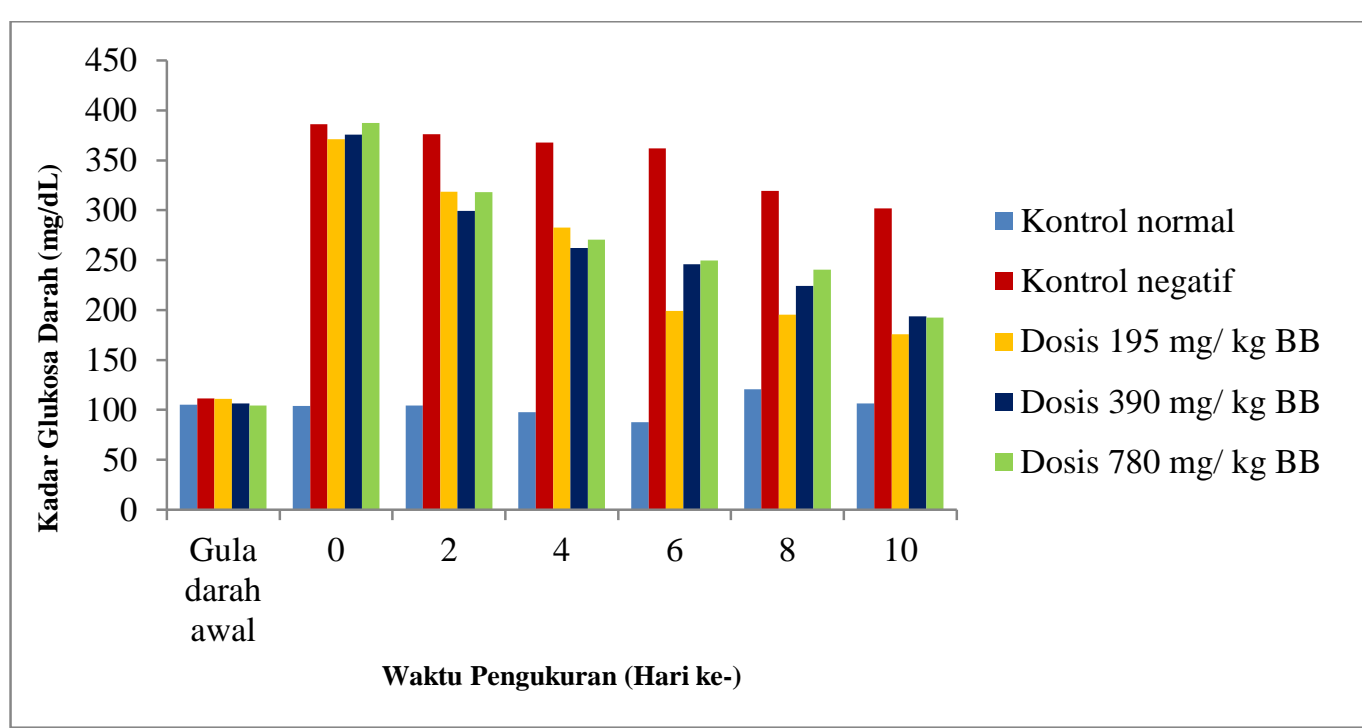

Gambar 1. Perbandingan Rata-rata Penurunan Kadar Glukosa Darah Mencit Pemberian Ekstrak Beras Ketan Hitam, Kontrol Negatif, dan Kontrol Normal

Pada diagram batang (Gambar 1) kadar glukosa darah awal merupakan kadar glukosa sebelum hewan uji diinduksi aloksan. Hari ke- 0 pada grafik menunjukkan kadar glukosa darah hewan uji dalam keadaan diabetes sebelum diberi perlakuan. Hari 2, 4, 6, 8, dan 10 
merupakan kadar glukosa darah hewan uji setelah diberi perlakuan. Pengukuran kontrol normal dilakukan sebagai parameter apakah ada pengaruh eksternal yang dapat meningkatkan kadar glukosa darah hewan uji seperti makanan, minuman, ataupun efek stress dari hewan uji.

Dilihat dari grafik tersebut terlihat ketiga variasi dosis ekstrak etanol beras ketan hitam memiliki aktivitas dalam menurunkan kadar glukosa darah dibandingkan dengan kontrol negatifnya. Data kadar glukosa darah dianalisis dengan ANAVA dua arah. Hasil analisis menunjukkan terdapat perbedaan yang sangat signifikan untuk waktu dan dosis terhadap penurunan kadar glukosa darah hewan uji kelompok kontrol negatif dan kelompok uji ekstrak dengan nilai $\mathrm{F}$ hitung dosis dan waktu $>\mathrm{F}$ tabel (F hitung dosis 13,95 $>\mathrm{F}$ tabel 2,76 (5\%) dan 4,13 (1\%); F hitung waktu 9,78 > F tabel 2,53 (5\%) dan 3,65 $(1 \%)$ ). Aktivitas penurunan kadar glukosa darah ini dapat dihubungkan dengan adanya metabolit sekunder yang berperan dalam menurunkan kadar glukosa darah seperti flavonoid tanin dan alkaloid. Flavonoid dapat mencegah komplikasi atau progresifitas diabetes melitus dengan cara menangkal radikal yang berlebihan dan memutuskan rantai reaksi radikal bebas. Flavonoid juga meningkatkan sensitivitas insulin dan memiliki efek penghambatan terhadap enzim alfa-glukosidase melalui ikatan hidroksilasi (Rosnani dan Marianne, 2011). Tanin mempunyai aktivitas hipoglikemik dengan meningkatkan glikogenesis dan berperan sebagai adstringent atau pengkhelat yang dapat mengkerutkan sel epitel usus halus sehingga mengurangi penyerapan sari makanan seperti glukosa sehingga laju peningkatan kadar glukosa dapat dihambat. Alkaloid bekerja dengan menstimulasi hipotalamus untuk meningkatkan sekresi Growth Hormone Releasing Hormone (GHRH), sehingga sekresi Growth Hormone (GH) pada hipofise meningkat. Kadar GH yang tinggi akan menstimulasi hati untuk mensekresikan Insulin-like Growth Factor-1 (IGF-1). IGF-1 memiliki efek menginduksi hipoglikemia dan menurunkan glukoneogenesis sehingga kadar glukosa darah dan kebutuhan insulin menurun (Prameswari dan Widjanarko, 2014).

\section{Dosis Efektif Ekstrak Beras Ketan Hitam Terhadap Penurunan Kadar Glukosa Darah}

Berdasarkan hasil analisis statistik ANAVA dosis efektif dapat diketahui dengan menggunakan uji lanjutan. Uji lanjutan dipilih berdasarkan hasil perhitungan Koefisien Keseragaman (KK). Hasil perhitungan diperoleh $\mathrm{KK}_{\text {dosis }}$ sebesar $188,91 \%$ dan $\mathrm{KK}_{\text {waktu }}$ sebesar 158,21\%, maka uji lanjutan dipilih adalah uji Perbandingan Berganda Duncan atau Duncan's Multiple Range Test (DMRT) dimana uji lanjutan ini dapat dilakukan jika KK besar (minimal 10\% pada kondisi homogen atau minimal 20\% pada kondisi heterogen). Berdasarkan hasil analisis statistik ANAVA dosis efektif dapat diketahui dengan menggunakan uji lanjutan. Uji lanjutan dipilih berdasarkan hasil perhitungan Koefisien Keseragaman (KK). Hasil perhitungan diperoleh KKdosis sebesar 188,91\% dan KKwaktu sebesar 158,21\%, maka uji lanjutan dipilih adalah uji Perbandingan Berganda Duncan atau Duncan's Multiple Range Test (DMRT) dimana uji lanjutan ini dapat dilakukan jika KK besar (minimal 10\% pada kondisi homogen atau minimal 20\% pada kondisi heterogen).

Hasil analisis Duncan diperoleh hasil sangat signifikan dengan nilai q hitung $(385,6$ pada dosis $195 \mathrm{mg} / \mathrm{kg} \mathrm{BB}$; 360,6 dosis $390 \mathrm{mg} / \mathrm{kg} \mathrm{BB}$; dan 371,2 dosis $780 \mathrm{mg} / \mathrm{kg} \mathrm{BB}$ ) > q tabel (91,24 pada taraf 5\% dan 121,22 pada taraf 1\%) dengan q hitung terbesar pada dosis $195 \mathrm{mg} / \mathrm{kg}$ BB. Hal ini menunjukkan dosis yang paling efektif dalam menurunkan kadar glukosa darah hewan uji adalah dosis $195 \mathrm{mg} / \mathrm{kg} \mathrm{BB}$.

\section{Perbandingan Penurunan Kadar Glukosa Darah pada Dosis Efektif Ekstrak Beras Ketan Hitam dengan Glibenklamid}


Perbandingan penurunan kadar glukosa darah pada dosis $195 \mathrm{mg} / \mathrm{kg}$ BB dapat dilihat pada gambar 2 .

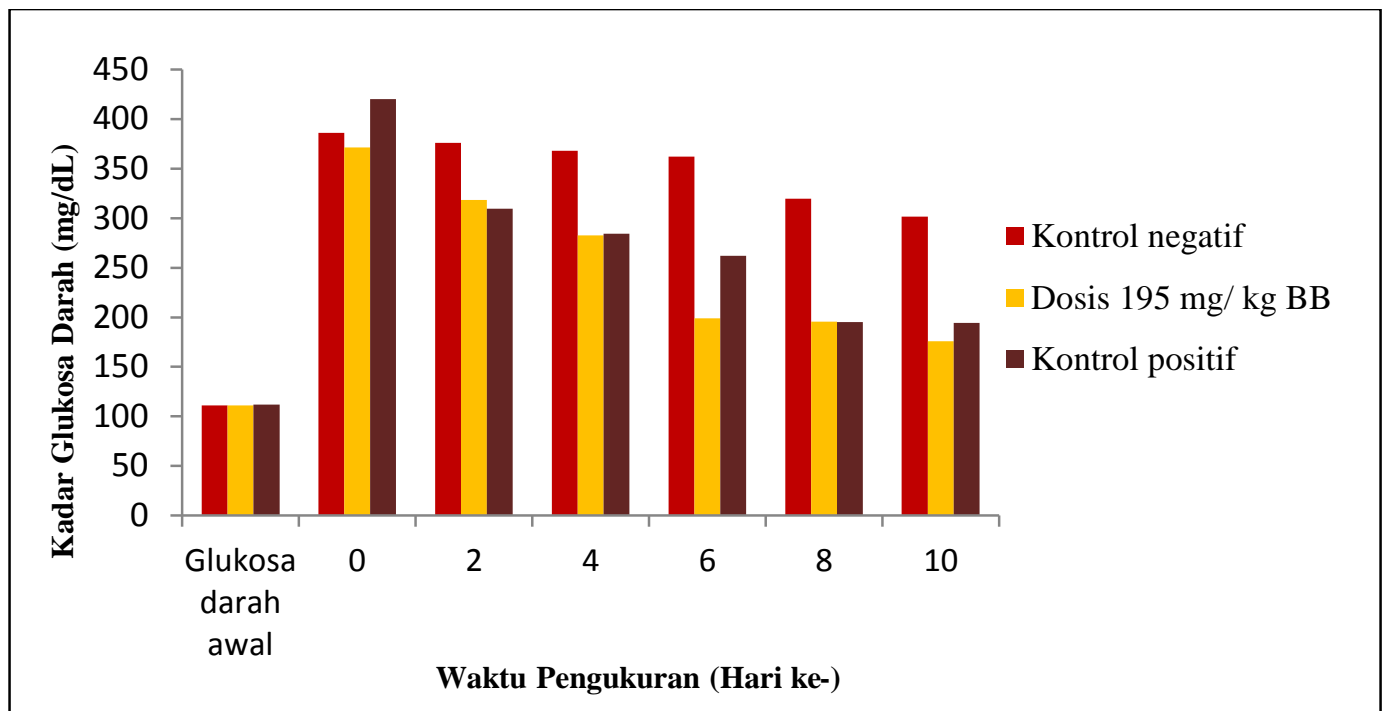

Gambar 2. Perbandingan Rata-rata Penurunan Kadar Glukosa Darah Mencit Dosis Terbaik, Kontrol Negatif, dan Kontrol Positif

Berdasarkan diagram batang (gambar 2) dapat dikatakan dosis $195 \mathrm{mg} / \mathrm{kg}$ BB dapat menurunkan kadar glukosa darah hewan uji pada kapasitas yang tidak jauh berbeda bila dibandingkan dengan Glibenklamid dan lebih baik dibandingkan kontrol negatifnya.

\section{KESIMPULAN}

Jumlah rendemen yang diperoleh dari ekstrak etanol beras ketan hitam (Oryza sativa L. var glutinosa) adalah 1,44\% dengan senyawa metabolit sekunder yang terkandung di dalamnya berupa golongan senyawa fenol, alkaloid, flavonoid, saponin, dan tanin. Ekstrak etanol beras ketan hitam memiliki aktivitas dalam penurunan kadar glukosa darah $(\rho<$ 0.01) dengan dosis efektif $195 \mathrm{mg} / \mathrm{kg}$ BB yang bila dibandingkan dengan Glibenklamid diperoleh nilai $\rho>0.05$ dalam menurunkan kadar glukosa darah.

\section{DAFTAR PUSTAKA}

1. Gustavani, R. dan Soegondo, S., 2007, Sindrom Metabolik: Buku Ajar Ilmu Penyakit Dalam Jilid III Edisi IV. Pusat Penerbitan IPD FKUI. Jakarta.

2. Burtis, C. A., Ashwood, E. R., dan Bruns, D. E., 2006, Lipids, Lipoproteins, Apolipoproteins, and Other Cardiovascular Risk Factor. In: Tietz Textbook of Clinical Chemistry and Molecular Diagnostic. Volume 1. St. Louis, Missouri. Elsevier.

3. World Health Organization (WHO), 2012, About Diabetes. Diabetes Unit. Switzerland.

4. Daud, N., 2013, Aktivitas Antidiabetes Ekstrak Daun Ubi Jalar (Ipomoea batatas) pada Mencit yang Diinduksi Streptozotocin. Tesis. Tidak Dipublikasikan. Universitas Sumatera Utara. Medan.

5. Katno dan Pramono, S., 2003, Tingkat Manfaat dan Keamanan Tanaman Obat dan Tanaman Obat Tradisional. Balai Penerbit FKUI. Jakarta.

6. Nailufar, A. A., Basito dan Anam, A., 2012, Kajian Karakteristik Ketan Hitam ( Oryza sativa glutinosa) pada Beberapa Jenis Pengemas Selama Penyimpanan. Jurnal Teknosains Pangan. Vol. 2. No.1: 122-132.

7. Medanense, Herbarium, 2011, Klasifikasi Ketan Hitam. Universitas Sumatera Utara. Medan. 
8. Depkes RI., 1996, Materia Medika Indonesia Jilid VI. Direktorat Jendral Pengawasan Obat dan Makanan. Jakarta.

9. Depkes RI., 1979, Farmakope Indonesia Edisi III. Departemen Kesehatan Republik Indonesia. Jakarta.

10. Depkes RI., 2000, Parameter Standar Umum Ekstrak Tumbuhan Obat. Cetakan Pertama. Departemen Kesehatan Republik Indonesia. Jakarta.

11. Lestari, A. B. S., dan Yohanes, D., 2014. Aktivitas Antioksidan Ekstrak Daun Sirih Merah (Piper crocatum) Hasil Optimasi Pelarut Etanol - Air. Jurnal Ilmu Kefarmasian Indonesia. Vol.21. No.1: 75-79.

12. Sihombing, C. N., Nasrul, W., dan Taofik, R., 2008, Formulasi Gel Antioksidan Ekstrak Buah Buncis (Phaseolus vulgaris L.) dengan Menggunakan Basis Aqupec 505 $H V$. Universitas Padjajaran. Bandung

13. Suharmiati, 2003, Pengujian Bioaktivitas Anti Diabetes Melitus. Departemen Kesehatan RI. Surabaya.

14. Rohilla, A., dan Ali, S., 2012, Alloxan Induced Diabetes: Mechanism and Effect. International Journal of Research in Pharmacetical and Biomedical Sciences. Vol. 3 No. 2.

15. Rosnani dan Marianne, Y., 2011, Antidiabetic Activity From Ethanol Extract of Kluwih's Leaf (Artocarpus camansi L.). Jurnal Natural Universitas Syiah Kuala. Vol. 11 No. 2.

16. Prameswari, M., dan Widjanarko, S. B., 2014, Uji Efek Ekstrak Air Daun Pandan Wangi terhadap Penurunan Kadar Glukosa Darah dan Histopatologi Tikus Diabetes Mellitus. Jurnal Pangan dan Agroindustri. Vol. 2 No. 2. 